\title{
Architectural Tendencies of Recent Infill Buildings in Kaunas Historic Centre
}

\author{
Eglè Navickienè, Vilnius Gediminas Technical University
}

\begin{abstract}
The aim of the paper is to define architectural tendencies, contextuality and impact on the surroundings of recent infill buildings built in Kaunas historic centre since 1990. The design of new buildings in Kaunas protected areas is not based on a regulated purposeful course; it expresses architectural evolution with constraints not efficient to direct the evolution according to progressive international recommendations.
\end{abstract}

Keywords - Contextuality, infill buildings, Kaunas historic centre, Lithuanian architecture in the Independence period, new architecture in a historic environment.

The paper deals with the problem of contextuality and the interrelationship between new architecture and its historic setting in the central parts of cities, where the problem is especially relevant and urgent. It is analysed concentrating on the case of the second largest Lithuanian city Kaunas, founded at the confluence of Nemunas and Neris - the largest Lithuanian rivers. Kaunas historic roots are special for the oldest stone castle in Lithuania and medieval, Renaissance and Baroque landmarks; in the $19^{\text {th }}$ century the town grew in originally planned, volumetric and spatial composition as a military town; in 1920 Kaunas became the capital of the independent Republic of Lithuania for two decades wherefore the unique interwar Modernist architecture following Bauhaus school and "the essential point of which was a desire for self-identification through historicism embodied in national heritage and classics" $[1,8]$ was concentrated there. Two protected bordering areas in Kaunas historic centre cover territories of specific stages of development rooting Kaunas identity: 1) the medieval Old Town and 2) the Historic part of the city formed in the $19^{\text {th }}$ century outstanding for interwar Modernist architecture. The research area cover the territories protected.

The author aims to define architectural tendencies, contextuality and impact on the surroundings of recent infill buildings built in Kaunas historic centre after regaining Lithuania's Independence in 1990. The architectural specifics and the contextuality of infill buildings are discussed according to the recommendations of that time, which embrace legal regulation of development in the protected areas of Kaunas central part, and tendencies towards the protection and development of urban heritage in the documents by international organizations. The development of general contemporary architectural tendencies predetermining architectural character and stylistics is also taken into account. The dynamics of evolution is revealed by the division into three characteristic periods: 1990-1999, 2000-2005 and 2006-2012. The periods are determined by changes in legal background and shifts in architectural tendencies.

The review of infill architecture in Kaunas central part is relevant and provoking compared to Vilnius case as they develop in quite different ways in spite of rather close location in the same state.
The main reasons for differentiation might be the capital factor and the UNESCO World Heritage site status of the historic centre of Vilnius followed by its elaborated regulation. Its specific preservation and development was discussed by the author in this journal in 2009 [2].

\section{LEGAL BACKGROUND AND RECOMMENDATIONS}

Infill construction is a specific sphere of architecture since, apart from overall architectural tendencies and regularities, infill architecture faces specific requirements to preserve urban heritage. The legal requirements for its preservation are formed by state laws and documents in a general scope, by declaration of protection status on urban heritage sites, and confirming documents or projects for their protection and development. In the Soviet times the protection and regulation of development of urban heritage territories coherent with the status of architectural or urban monument started in the very beginning of 1960s and at first took place only in several Lithuanian medieval Old Towns. Compared to other European countries, the initial process of urban heritage preservation in Soviet Lithuania was rather early, progressive and well-allocated. After regaining Lithuania's Independence in 1990 the situation changed, as in the scope of Lithuanian urban heritage, the attention was focused on Vilnius historic centre, which gained the UNESCO World Heritage site status in 1994 and afterwards had several conservation and development documents and projects accomplished and confirmed. However, the elaboration of legal background for protection and development of urban heritage in other Lithuanian cities is very slow and non-productive.

Likewise in other Lithuanian towns, in Kaunas the Old Town had the status of architectural (1961) and urban (1969) state monument during the Soviet times. In 1996, its territory was

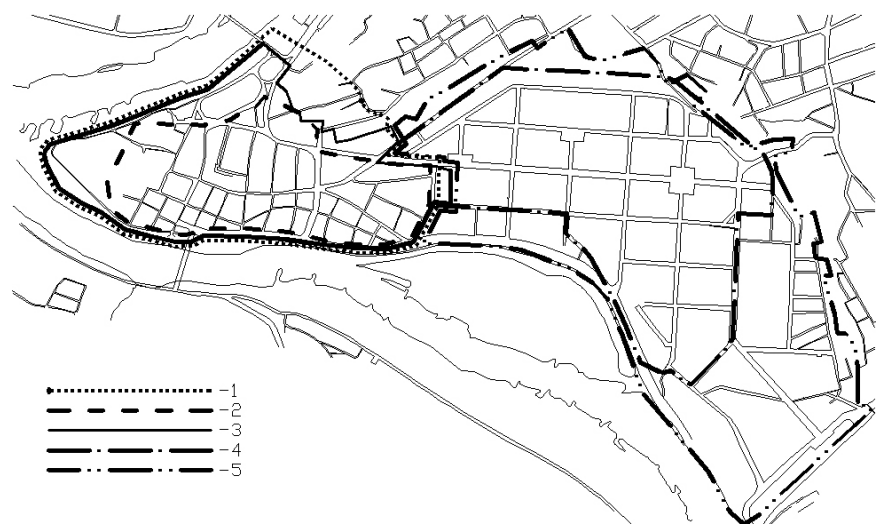

Fig. 1. The change and growth of territories of urban heritage sites in Kaunas historic centre. Old Town: 1 - LSSR urban monument (1969), 2 - LR cultural monument (1996), 3 - LR cultural monument (2010); Historic part of the city: 4 - LR cultural monument (1999), 5 - LR cultural monument (2012). 
revised as the status of state cultural monument was received; its boundary was revised once again in 2010 (Figure 1). In the Soviet times the status of architectural (urban) monument came along with Old Town Regeneration Projects; without deepening into qualitative aspects, the urban heritage, besides legal status, had documents for protection of values and guidelines for development. After 1990, when the legal basis for protected urban sites was concentrated on the historic centre of Vilnius the UNESCO World Heritage site, protection of Kaunas Old Town was supported only by brief Main File of Cultural Property (1996). In 2010 the LR Culture Minister confirmed a Detailed Plan of Kaunas Old Town specifying levels and ways for protection of its material fabric [3].

The legal protection of Kaunas historic part of the city was set in 1999. Initially, its protection was supported by brief Main File of Cultural Property (1999). LR Culture Minister confirmed a Detailed Plan of Kaunas historic part of the city (2012) specifying levels and ways for protection of its material fabric in an expanded territory (Figure 1) [4].

As the last development project for urban heritage territory the Old Town Regeneration Project (1977) is out of relevance, there are no objective elaborated legal documents, projects or guidelines establishing protection and development for further evolution of territories of Kaunas Old Town and historic part of the city. These territories were analysed as part of Kaunas in the works of urban heritage research $(1993,2006)$, master planning (2003) and allocation of high-rise buildings (2006). Anyway, these works state generalized recommendations for overall urban heritage sites without differentiation.

Without elaborated documents and projects the protection and development of Kaunas urban heritage is not based on a regulated purposeful course. Moreover, regulation of evolution of Kaunas central part stands behind the contemporary treatment: conception of heritage preservation and development as constituent parts of the same process; the principle of preservation as prohibition turning to a principle of regulated development [5, 204-205] that should evolve from the genetic program, providing identity to a city that is enshrined in a specific storage - Old Town - and continued in further stages of historic evolution; any urban activities of community should implement this program for specific evolution to anchor the identity and oneness [6, 232-233].

Apart from a local legal background, the trends towards the protection and development of urban heritage in the documents by international organizations (UNESCO, ICOMOS and Council of Europe) are very important as the methodology basis for the design of architecture in protected areas and their positions as criteria for its evaluation. During the period discussed, the evolution of the principles of urban heritage conservation developed towards territorial spread and heterogeneous multilayering. The preservation and continued existence of urban heritage "forms an essential element of the development of the city as a whole" [7].

Started with urban-structural and formal-compositional integration of a new object into urban heritage situation that ensures visual and compositional compatibility; reflection of character that embraces qualities of buildings, spaces, functions and social diversity; continuity of traditional building materials,

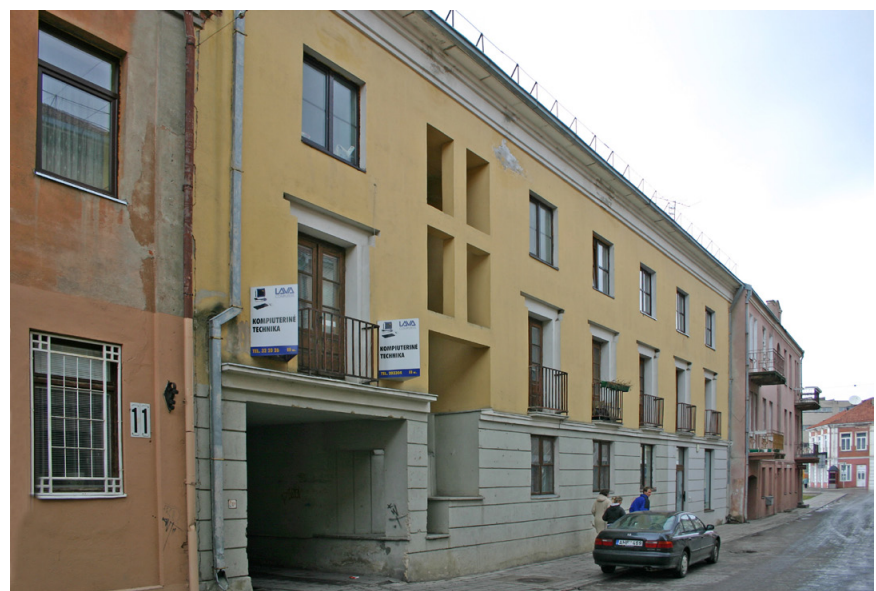

Fig. 2. Dwelling building on Kumelių Str. (built in 1993) [a photo by the author].

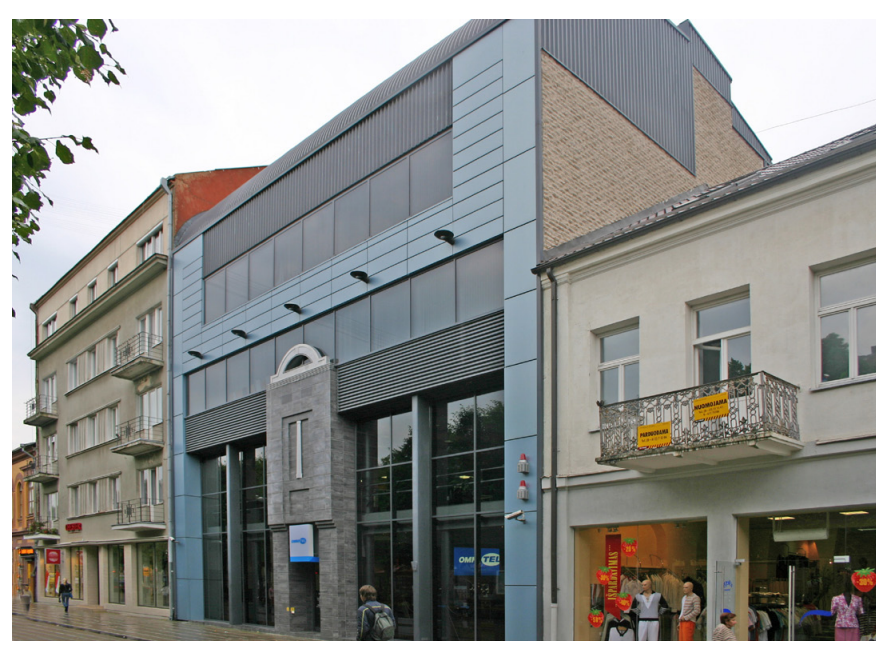

Fig. 3. Administrative building "Omnitel" on Laisvès Alley (built in 1998) [a photo by the author]

technology and crafts using them in contemporary manner; later on following traditional patterns, continuity of a place's intangible values, the spirit of place, and social experience was added [8]. Recent new challenge is high-quality architectural standards for contemporary architectural elements. Vienna Memorandum on "World Heritage and Contemporary Architecture - Managing the Historic Urban Landscape" (UNESCO, Vienna, 2005) emphasizes three major keystones for infill architecture: continuity of culture through quality interventions, avoiding pseudo-historical design [9].

\section{PERIOD OF 1990-1999}

Since 1990, the first decade has been a specific period in practice of infill architecture outstanding for several reasons. The regaining of Independence by Lithuania was followed by a deep economic decline that resulted in a small number of buildings erected facing the streets of Kaunas Old Town and the historic part of the city. After liberation from the Soviet pressure and dictate, the society was greatly concerned with heritage preservation as a national treasure and guarantee of its identity, and especially sensitive to what was happening in the urban heritage places. 


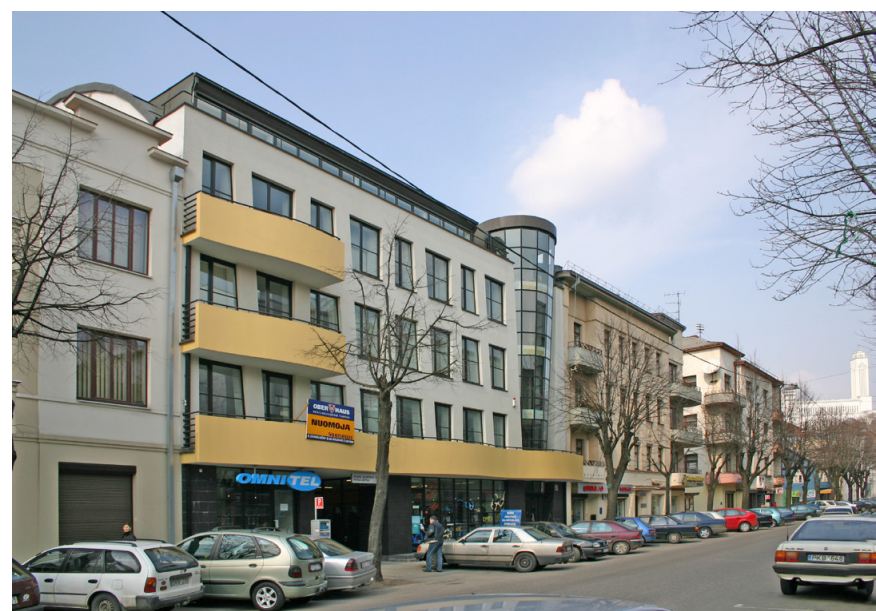

Fig. 4. "ABP German Invest” building of offices for rent on A. Mickevičiaus Str. (built in 2001) [a photo by the author].

As V. Petrušonis notices: "first years after 1990 stand out by romantic will to continue an interwar tradition of Kaunas architecture" [10, 16]. Moreover, the Post-modern style in architecture that was still on its peak at that time, declared contextuality and the use of architectural language based on a historical or regional origin. Certain postulates of Post-modern movement, such as contextuality, regionalism, reference to semantic and symbolic codes, and focus on historic tradition, overlap with contemporary positions expressed in international recommendations and theory for infill architecture. All these circumstances formed a specific background for infill architecture with a few possibilities for fast, numerous and radical changes to occur in the central historic area of Kaunas. The buildings that were erected were rather uniform in spite of the fact that the Old Town had a status of urban or cultural monument, and the historic part of the city did not have such a status.

Buildings constructed in the Old Town of Kaunas at that time followed the same pattern: overall shape and height coordinated with neighbouring buildings; tectonic structure of massive wall and ordered openings; horizontal division into basement, main and cornice parts; small scale created by usage of relief, graphic cutout, framings of windows; details and elements associated with historic architecture. The architectural language was based on the transformation of historic elements in a Post-modern way: an ironic approach in reverse relief of framing of windows in a dwelling building on Kumelių Str. (Figure 2); play of distorted geometric shapes of portal and cornice part in an administrative building on šv. Gertrūdos Str. The architectural expression was low; the relationship to the surroundings was passive. Buildings of the period are similar in a contextual approach and tolerant relationship to the context as they were integrated into the surroundings in a harmonious and careful way.

Social expectations and Post-modern style determined specific architectural tendencies of the infill buildings of the period in the historic part of the city before legal restraints were set. The architecture of part of the buildings of that time is rather similar to those built in the Old Town in architectural expression, relationship to the context, finish in plaster and colours characteristic of the environment, like in the architecture of the premises of Vytautas
Magnus University on K. Donelaičio Str. that interprets historic character in a geometric interplay with adjoining buildings.

Two buildings: administrative building "Omnitel" on Laisvès Alley and hotel "Daniela" on A. Mickevičiaus Str. might form the other part of infill architecture in the historic part of the city that appeared in the very end of the period foretelling about coming changes. They were treated quite brave and radical at that time because of finish in colourful metal sheets and non-traditional elevation structure: slanted horizontal lines of hotel "Daniela" elevation in a deconstructive manner and its black-and-white colours create fresh contrast to neighbourhood; administrative building "Omnitel" features a rounded roof and is finished in blue metal sheets (Figure 3). Anyway, the buildings' height, position, urban and architectural scale corresponds to the ones characteristic of environment; thus, the expression of mentioned buildings is equivalent to the neighbourhood avoiding declarative contrast and destructive impact on the surroundings.

It should be emphasized that contextuality, cautious expression and tolerant relationship to the environment in architecture of buildings constructed in the central historic part of Kaunas during the period of 1990-1999 were not a pure result of legal regulation or methodical reference to theory and guidelines for infill architecture, they mostly represented a mainstream of contemporary tendencies in architecture reacting to social expectations that were overlapping with treatment recommended internationally. In comparison, tendencies of infill architecture in the historic centre of Vilnius were rather similar; however, the method of historical reconstruction had already been used (dwelling buildings on Didžioji Str., 1998).

\section{PERIOD OF 2000-2005}

The 21 st century started with an economic growth in building sectorup to the building boom that took place all over the Lithuanian cities, and in the historic centre of Kaunas (except the Old Town). The legal protection of the historic part of the city was established in 1999; however, it was not followed by detailed documents, projects or guidelines. Thus, it did not change the way new buildings were designed - as the contemporary representations of the city centre. Search for identity, obedient respect and nostalgia for the cultural heritage of Kaunas, especially for its pride - the interwar period architecture that dominated during the previous period was shrinking; the ambition to match up to European cities took over its place: during the period presented the Spanish architecture as the source of aspiration for Kaunas architects was turning to the Dutch one [11].

The tendency of previous period is continued only in two administrative buildings in the historic part of city, standing one beside the other on A. Mickevičiaus Street. "ABP German Invest" building of offices for rent respectfully transforms the main features of the key buildings from interwar period architecture in a deconstructive manner (Figure 4), while the building of Kaunas Department of the State Social Insurance Fund Board retains a conservative rational tradition of building structure and compositional scheme with a highly expressed horizontal and vertical division. Architecture of both buildings corresponds to the point of view of previous period as they were designed a few years before they were erected - that is why originally and 
ideologically they represent the attitudes of the last decade of 20 th century.

A majority of newly built buildings in the historic part of city followed the architectural stream dominating in Lithuania: reduction of complexity of artistic expression, abstraction and purification of shapes. New priorities in design left aside history and past turned buildings to a uniform - once again - shape of minimalistic boxes of glass or concrete irrespective of building location. The objective for morphological simplicity and ascetics in exterior rejected any relief and small-scale elements in elevations; harmonizing compositional division was reduced to a graphic pattern of frames. Lack of elaborated details did not help to balance the architectural scale to the surrounding one; although the urban scale, position and height were contextualized due to the regulation. The general description of main architectural tendency confirms verbatim to several examples: glass walls of a commercial building and a commercial-administrative building on Laisvès Alley; glass surfaces in a more complex shape of "Swedbank" headquarters on Maironio Str.; combination of curved concrete and glass surfaces in commercial building "Sostinè" on Maironio Str. (Figure 5); combination of glass and brick in a flat surface in an administrative building on Jonavos $g$. the only one located in the Old Town.

Infill buildings featuring innovative expression, cosmopolite design ignoring local features, materials and architectural scale in contrast to the characteristic ones make an active but controversial impact on their historic surroundings. Their impact should be evaluated deciding what the priority for the development of the central part of Kaunas is - should it be treated as a contemporary cosmopolitan centre or as on-going evolution of urban heritage providing the identity for the city? The international documents and guidelines recommend the latter priority [7], [8], [9], and many examples confirm that both priorities might be combined successfully. Without elaborated background for the protection and development of the historic part of the city, the responsibility for the contextuality of infill architecture emerging there was left for architects and local officials. Thus, the lack of contextuality might be explained by the shortage either of specialists' knowhow or the respect for urban architectural heritage.

Infill architecture in the historic centre of Vilnius at the same time was taking another direction. Legal regulation was focused on the historic tradition with limited contemporary expression (motivated by preservation of the values of the World Heritage Site). In cases when an infill object was not based on the historic vocabulary, it became less and less a pure piece of contemporary architecture and more and more - a composite answer to a complicated regulation decreasing architectural quality.

\section{PERIOD OF 2006-2012}

The last period covers the decline in Lithuanian economics from building boom to recession. The architecture of infill buildings of this period, compared to the earlier ones, is mostly heterogeneous. The difference depending on the heritage site (Old Town or the historic part of a city) emerged: the interventions into the Old Town were more contextualised, sensitive and based on traditional patterns; interventions into the historic part of a city featured innovative expression, use of non-traditional materials

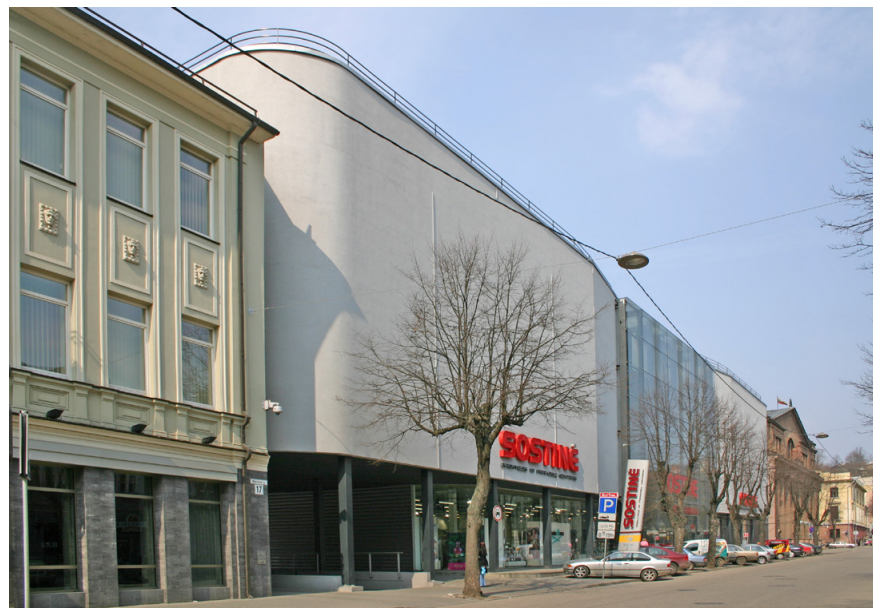

Fig. 5. Commercial building "Sostinè" on Maironio Str. (built in 2003) [a photo by the author].

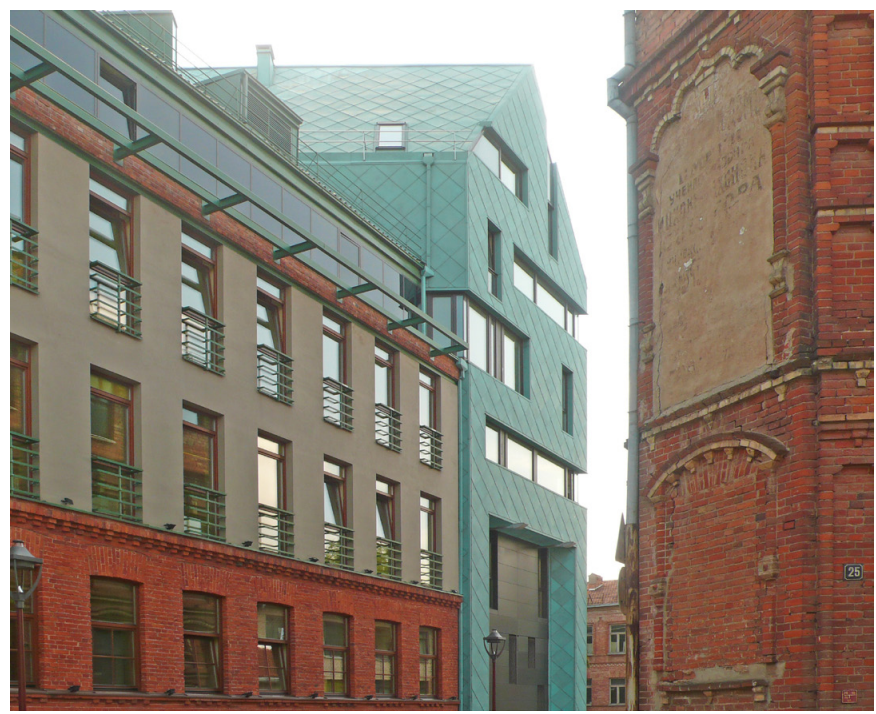

Fig. 6. "Santaka" hotel extension on Gruodžio Str. (built in 2007) [a photo by the author].

and technologies, and liberal approach, part of them - even of destructive nature.

Since 1990, the only reconstruction project has been implemented in Kaunas stone castle. Volumes of lost fragments upper part of a tower and part of a wall have been recreated in red brick openwork. Modern technology leaves no doubt about its building time and is methodologically reasoned. Anyway, it raised hot discussions in the society whether it was purposeful and right.

Other buildings in the Old Town adapt a characteristic urban and architectural scale, average height and typical roof shape, searching for and reinterpreting the spirit of place. Local features and patterns are not repeated directly in a retrospective way. In an apartment house on Karaliaus Mindaugo Str. they are transformed less, building elements are organized in almost traditional way and a small scale is achieved by play on surface relief. Other examples present an abstracted building shape eliminating or reducing structural elements like roof and base. Purified shape is divided by windows as in an apartment quarter on Santakos Str., 


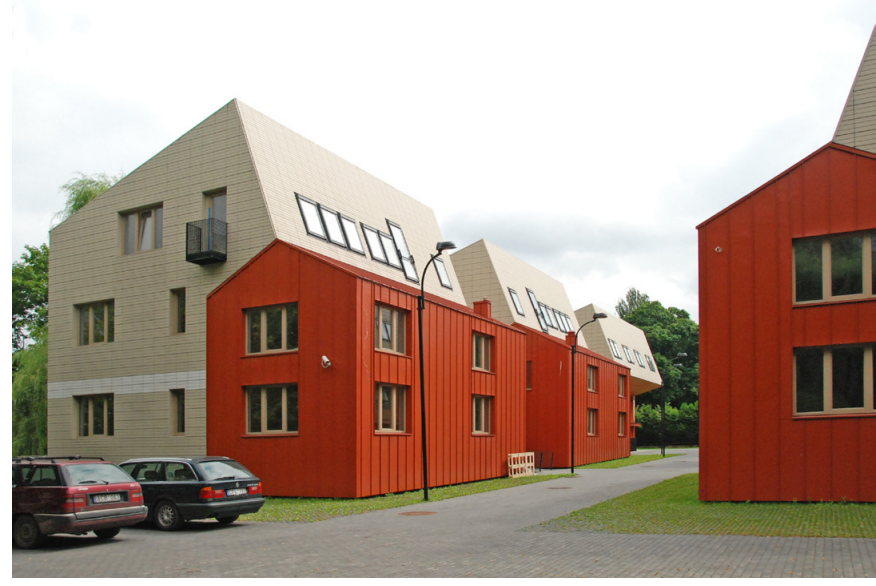

Fig. 7. Apartment quarter on Santakos Str. (built in 2008) [a photo by the author]

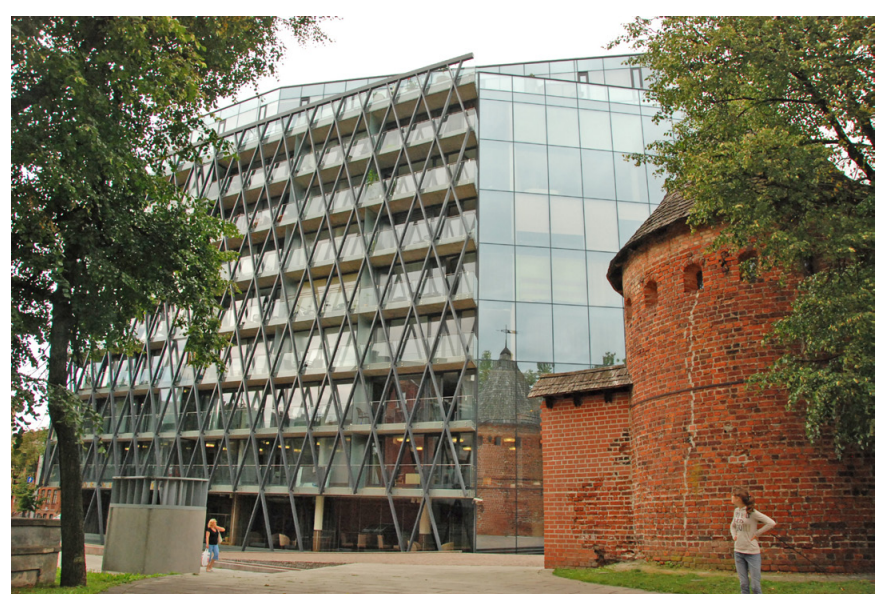

Fig. 8. Multifunctional complex "Bokštas" on Kęstučio / I.Kanto Str., (built in 2007) [a photo by the author].

or by prolonged stripes of openings like in the Kolping University of Applied Sciences on Raguvos Str., Jesuitical Gymnasium on Daugirdo Sstr., and "Santaka" hotel extension on Gruodžio Str. (Figure 6). Talking about "continuity of culture through quality interventions" as the essential requirement for infill architecture stated in recent international recommendations [9], the Jesuitical Gymnasium and "Santaka" hotel extension are the leaders as the first one attempts to catch the ascetic mood and rhythm of squeezed Daugirdo bystreet and the latter one interprets a character of Gruodžio Str. characteristic of higher and more decorative historicism buildings by an irregular play of prolonged shapes. Both infill buildings are non-conformist and active but sensitive imprints of high-quality contemporary architecture. The apartment quarter on Santakos Str. does not properly meet the requirements for its formal and stiff manifestation in especially sensitive location right beside the confluence in the very core of the Old Town; lacking of precise details and building quality, its architecture balances on impression of poorness rather then desired purity (Figure 7).

Hardly any building in this period erected in a historic part of the city appeared without a notice in mass media for rejection of professional community, in oppositionto society or legal variance. The largest harm to the historic part of Kaunas was done during

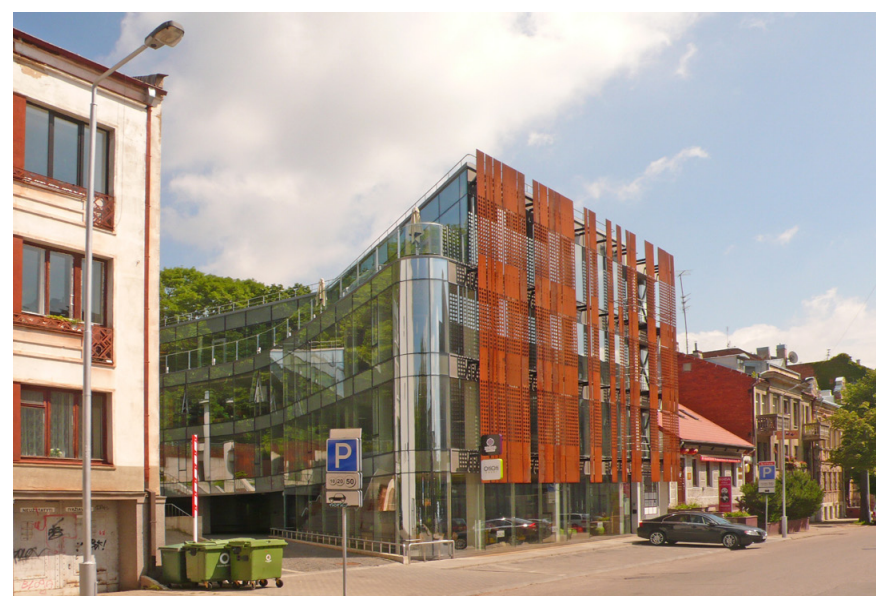

Fig. 9. Business centre "Capital" on Putvinskio Str. (built in 2009) [a photo by the author].

this period by buildings ignoring respect for an existing urban situation and demand for the development of urban heritage place. The huge commercial centre "Akropolis" built on a bank of river totally changed the urban structure and scale of the historic part of Kaunas as it covered the territory of the size of whole quarter together with part of embankment street and put into its shade the Karmelitu church standing close to it; apart from heritage and urban issues, it distorted a social and economic life in Kaunas centre. Another drastic intervention was a 10-storey multifunctional complex "Bokštas" on the boundary of Old Town that changed the balance of heights; the segment of medieval defence wall with a tower right beside it lost their marking silhouette and they were overshadowed in the background of active elevation design (Figure 8). Confusing urban invasions were conditioned by pressure of investors and enabled by missing institutional potency to withstand it. A. Lamauskas searches for reasons for aggressive changes in globalization influences and social liberalization [12]. It should be mentioned that Kaunas architecture experts are not unanimous as J. Bučas advocates the existence of multifunctional complex "Bokštas" as the reflecting glass background for exposition of heritage objects [13, 150-152].

The infill objects of less extreme relationship towards the historic part of the city are pieces of contemporary innovative architecture, active elements of environment like business centre "Capital" on Putvinskio Str. (Figure 9). Although most of recent buildings are finished in glass and metal, the approach declared is different from the one of the previous period due to efforts undertaken to contextualise the scale, harmonize a compositional scheme and colours that result in better relationship to the context in urban, architectural and compositional aspects.

Meanwhile recent architectural realizations in the historic centre of Vilnius continue the course of a limited contemporary architectural approach in favour of historicist design restraining sustainable cultural evolution and freezing the image of urban structure at a certain historical stage.

\section{Conclusions}

Kaunas historic core and source of identity - Old Town and the historic part of the city lack an elaborated legal background 
for protection and development as an integral sustainable process (the latter component has not been initiated yet) meeting the contemporary point of view. Present time of economic decline should be used to come up with a progressive outlook, strategy, documents and projects. To date the process of the design of new buildings in Kaunas protected areas is not based on a regulated purposeful course balanced with contemporary recommendations emphasizing sensitivity to the cultural-historical context and high architectural quality. It relies on subjective circumstances and human factor, such as the professional qualification and knowhow of architects and local officials, responsible for the approval of a project that leaves gaps for initiatives of the investors and unjustified decisions.

Since 1990, the design of infill architecture in the historic central part of Kaunas little depended on legal status of urban heritage site and its protection; mostly it depended on contemporary architectural tendencies, as well as on professional competence, social expectations, pressure of investors, and culture standards. In the period of 1990-1999 infill architecture was uniform in a contextual careful approach, low Post-modern expression and passive impact on the environment. In 2000-2005 it was uniform in a cosmopolite design, innovative expression and active impact on the surroundings. During the period of 2006-2012 it is heterogeneous comprising harmonized contemporary architecture and active innovative buildings, part of them - aggressive radical interventions into an urban heritage site.

The overall tendency of infill architecture in Kaunas central part displays rising contextuality due to gaining of know-how and experience, and growing diversity, including a negative practice. Compared to tendencies of infill architecture in the historic centre of Vilnius, process in Kaunas is rather different from the one in Vilnius as it expresses even and natural architectural evolution with constraints almost sufficient to avoid rough mistakes but not efficient to direct the evolution according to the guidelines pointed out by progressive international thought and recommendations.

\section{REFERENCES}

1. Baužienè, M. Lietuvos moderno pastatai : Lithuanian Monuments of Modern Movement. Vilnius: Savastis, 1998.80 p.

2. Navickienè, E. New Buildings in Vilnius Historical Centre: in Between of Replication and Innovation. Scientific Journal of Riga Technical University : Architecture and Urban Planning = R̄̄gas Tehniskās universitātes Zinātniskie Raksti : Arhitektūra un pilsētplānošana. Rīga: RTU, 2009, Vol. 10, Issue 4, p. 119-128.

3. Kauno Senamiesčio (unikalus objekto kodas 20171, buv. kodas U15) nekilnojamojo kultūros paveldo apsaugos specialusis planas. Aiškinamasis raštas [online]. Department of Cultural Heritage, 2010 [cited 27.07.2012]. http://www3.lrs.lt/pls/inter3/dokpaieska.dok_priedas?p_id=43191

4. Kauno Naujamiesčio (unikalus objekto kodas 22149, buv. kodas U30) nekilnojamojo kultūros paveldo apsaugos specialusis planas. Aiškinamasis raštas [online]. Department of Cultural Heritage, 2012 [cited 27.07.2012]. http://tar.tic.lt/getfile.aspx?AktoId=3D1C9D50-D858-4C87-9D86888ACF2A7B9D\&doctype $=2$

5. Bučas, J., Čepaitienè, R., Gražulevičiūtè-Vileniškė, Mlinkauskienė, A. Paveldas Lietuvos statybų vizijos kontekste. Urbanistika ir Architektūra, Vol. 31, Issue 4, 2011, p. 201-212.
6. Rubavičius, V. Vilniaus senamiestis - gyvosios kultūrinès atminties šerdis. Urbanistika ir Architektūra, Vol. 35, Issue 4, 2011, p. 231-237.

7. Suzhou Declaration on International Co-operation for the Safeguarding and Development of Historic Cities [online]. UNESCO, 1998 [cited 27.07.2012]. http://whc.unesco.org/archive/suzhou.htm

8. The Quebec Declaration on the Preservation of the Spirit of the Place [online]. ICOMOS, 2008 [cited 27.07.2012]. http://www.international.icomos.org/ quebec2008/quebec_declaration/pdf/GA16_Quebec_Declaration_Final_ EN.pdf

9. Vienna Memorandum on World Heritage and Contemporary Architecture Managing the Historic Urban Landscape [online]. UNESCO, 2005 [cited 27.07.2012]. http://whc.unesco.org/uploads/activities/documents/ activity-48-3.doc

10. Petrušonis, V. Kauno architektūra: dešimtmečio retrospektyva. Archiforma, 2 (2002), p. 16-24.

11. Tuleikis, L. Ką groja ir kuo serga Kauno architektai. Archiforma, 2 (2002), p. 68-69.

12. Lamauskas, A. Gobalizacija: gèrio ir blogio priešprieša (apie globalizacijos reiškinius urbanistinèje ir architektūrinèje aplinkoje). Archiforma, 3-4 (2011), p. 65-69.

13. Bučas, J. Demokratiniai proveržiai paveldosaugoje. Urbanistika ir Architektūra, Vol. 30, Issue 3, 2006, p. 143-158.

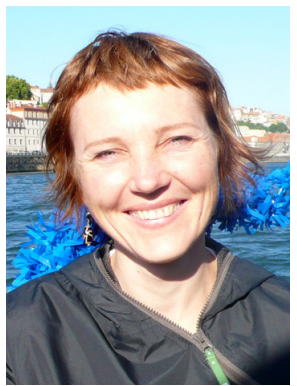

Eglė Navickienė (Šiauliai, 1974). B. arch. (1996), MSc. arch. (Vilnius Technical University, 1999), Dr. arch. (Vilnius Gediminas Technical University, 2004), PhD research thesis New Architecture in the Historic Environment of the Largest Lithuanian Cities (1950-2003), tutor Prof. Dr. habil. Algimantas Miškinis.

ASSOCIATED PROFESSOR at the Department of Architecture, Vilnius Gediminas Technical University (VGTU). VICE-DEAN FOR RESEARCH at the Faculty of Architecture, Vilnius Gediminas Technical University (VGTU). Guest lecturer at Kaunas Arts Academy, Kaunas Technology University, Kyungpook National University, South Korea. He is a participant of scientific conferences and the author of 10 scientific publications, including a monograph.

Previous publications:

- Navickienè, E. Nauja architektūra istorinèje aplinkoje: kūrimo patirtis (New Architecture in a Historic Environment: Experience of Design Practice). Vilnius: Technika, 2006, ISBN 9955-28-060-3. 180 p.

Current and previous research interests: new architecture in a historic environment, protection of urban heritage, architectural composition.

\section{Contact Data}

Eglè Navickienè

Vilnius Gediminas Technical University, Faculty of Architecture Address: Pylimo g. 26/1, Vilnius, LT-01132, Lithuania

Phone: + 37052745211

E-mail: eglen@vgtu.lt 